\title{
Investigation of the Effect of Sodium Selenate on Acetylcholinesterase Activity under Extremely Low Frequency Electromagnetic Field
}

\author{
Ezzatollah Fathi \\ University of Tabriz, Faculty of Veterinary Medicine, Imam St \\ PO Box:5166616471, Azadi Ave., Tabriz-Iran \\ Tel: 9-841-1339-2351Ｅ-mail: ez.fathi@tabrizu.ac.ir \\ Raheleh Farahzadi (Corresponding author) \\ Department of Clinical Biochemistry, Faculty of Medical Sciences \\ Tarbiat Modares University
}

PO Box: 14115-331, Jalal Ale Ahmad Highway, Tehran, Iran

Tel: 9-821-801-1001Ｅ-mail: r. farahzadi@modares.ac.ir

Received: August 26, 2012 Accepted: September 8, 2012

doi:10.5296/jbls.v4i1.2296 URL: http://dx.doi.org/10.5296/jbls.v4i1.2296

\begin{abstract}
Acetylcholinestrase (AChE EC 3.1.1.7) is one of the most important enzymes in nervous system, which plays a role in Alzheimer's disease. Selenium is a vital micronutrient and many investigations have been performed about the physiological, biochemical and behavioral effects of this element, such as postponing the Alzheimer's symptoms in the elderly and delaying the initiation signs of skin aging. Recent studies have shown that this element protects various enzymes against the toxicity caused by heavy metals such as; $\mathrm{Pb}, \mathrm{Al}$, $\mathrm{Cu}$ and $\mathrm{Cd}$. AChE activity is altered under the influence of extremely low frequency electromagnetic field (ELF-EMF). In this study, the effects of ELF-EMF, with $0.3 \mathrm{mT}$ field intensity and 50,100, $217 \mathrm{~Hz}$ frequencies, were investigated on the $\mathrm{AChE}$, in the presence of different concentrations of sodium selenate, using UV-Visible, fluorescence and circular dichroism spectroscopic techniques. The results demonstrated that the enzyme activity declined by increasing the frequency and the amount of sodium selenate. Also, significant structural changes occurred in the secondary and tertiary structures of AChE. Our results
\end{abstract}


showed that with increasing the concentration of sodium selenate transition from $\alpha$-helix to $\beta$-structure was appeared in the presence of ELF-EMF. In conclusion, according to changes observed in the secondary and tertiary structure of enzyme, it is proposed that these fields are able to affect the structure and dynamics of the active site gorge of AChE.

Keywords: Acetylcholinestrase, Circular dichroism spectroscopy, Extremely low frequency electromagnetic field, Fluorescence spectroscopy, Sodium selenate, UV-visible spectroscopy

\section{Introduction}

Daily exposure to electromagnetic field is unavoidable as a consequence of living in a Society that depends heavily on the use of electricity. Humans are normally exposed to extremely low frequency electromagnetic fields (ELF EMFs; defined as having a frequency of less than $300 \mathrm{~Hz}$ ) (Yaghmaei et al., 2009). Various surveys and epidemiological studies (Yaghmaei et al., 2009) have been performed to find the effects of these ELF EMFs. The exposure to ELF EMFs influences the cell proliferation rate and enzyme activities as well (Zwirska-Korczala et al., 2005). Previous studies have reported that ELF EMFs with the frequency of $75 \mathrm{~Hz}$ and amplitudes above $250 \mu \mathrm{T}$ threshold caused a 55\% decrease in the enzymatic activity in the outer segment membranes of retinal rod cells (Ravera et al., 2004). Other studies have demonstrated that ELF EMF with the frequency of $75 \mathrm{~Hz}$ and amplitudes above a $250 \mu \mathrm{T}$ threshold decreases the activity of three membrane-bound blood cell- or synaptosome- enzymes: alkaline phosphatase, phosphoglycerate kinase and Acetylcholinestrase (AChE) up to 54-61\%. Insignificant effects of ELF EMF have already been reported on the activities of soluble enzymes (Morelli et al., 2005). Therefore, in the present study, the hypothesis is that ELF EMF affects the activity of AChE, which occurs at high specific activity in the brain and nervous tissues. AChE is usually found in several forms. Mammalian brain AChE consists almost exclusively of globular forms, principally the tetrameric one (Dvir et al., 2004). AChE catalyzes the hydrolysis of acetylcholine (ACh) into acetate and choline at the cholinergic nerve terminals. It is, therefore, remarkable that the active site of this enzyme is found at the bottom of a deep and narrow gorge (Axelsen et al., 1994). We do not yet know whether this gorge provides a mechanism that somehow facilitates the rapid action of AChE. Selenium is an element that is essential for normal metabolic reactions in the body (Ani et al., 2007), and seems to reduce the toxicity of several metals probably by forming the selenide complexes (Ani et al., 2007; Moshtaghie et al., 2007). Selenium is also known to provide protection from reactive oxygen species (ROS) induced cell damages. Therefore, in this regards, the selenium has been shown to reverse some effects of ELF EMF on the AChE in vitro.

\section{Materials and Methods}

AChE [(EC 3.1.1.7 from Electrophorus electricus (electric eel)] was purchased from Sigma TM Chemical and Biochemical Company. Sodium selenate $\left(\mathrm{Na}_{2} \mathrm{SeO}_{4}\right)$ was synthesized as explained earlier. All other materials and reagents were of analytical grade. The reported results in this paper are the outcome of triplicate measurements.

\subsection{Enzyme Assay}


AChE activity was determined at $25^{\circ} \mathrm{C}$ by the spectrophotometeric method of Ellman (Ellman et al., 1961), based on the following colorimetric reactions:

Acetylthiocholine iodide $\underset{\mathrm{AChE}}{\longrightarrow}$ Thiocholine + Acetate

Thiocholine + Dithiobisnitrobenzoic acid (DTNB) $\longrightarrow$ 5-thio-2-nitro-benzoat (yellow)

The reaction mixture containing the $3 \mu \mathrm{M}$ AChE with the $12.5 \times 10^{-6} \mathrm{M}$ acetylthiocholine iodide (ACh iodide) with different concentrations of $\mathrm{Na}_{2} \mathrm{SeO}_{4}(0,390,870,1300$ and 1800 $\mu \mathrm{M}$ ) was kept in the electromagnetic fields $50,100,217 \mathrm{~Hz}, 300 \mu \mathrm{T}$ for $30 \mathrm{~min}$ at $4^{\circ} \mathrm{C}$ and immediately after the DTNB was added to the reaction mixture the enzymatic activity was measured for $10 \mathrm{~min}$ in the absence of the field. The principle of the method is the measurement of the rate of production of thiocholine as acetylthiocholine iodide is hydrolyzed. This is accomplished by the continuous reaction of the thiol with DTNB (Ellman reagent) to produce the yellow anion of 5-thio-2-nitro-benzoat. The rate of color production was measured at $412 \mathrm{~nm}$ for $10 \mathrm{~min}$ with a UV-spectrophotometer Shimadzu, model UV-3100 with jacketed cell holders. All the experiments were run in phosphate buffer $(0.1 \mathrm{M})$ at pH 7.4 in conventional thermostated quartz cell to maintain the temperature at $20 \pm 0.1{ }^{\circ} \mathrm{C}$. The initial velocity of enzyme was calculated using an absorption velocity of enzyme calculated using an absorption coefficient, $\varepsilon=1.36 \times 10^{4} \mathrm{M}^{-1} \mathrm{~cm}^{-1}$ and one unit of enzymatic initial velocity is given as $\mu \mathrm{mol} / \mathrm{min}$ (Hekmat et al., 2008).

The rate calculated from the equations:

$\Delta$ absorbance/min

$\operatorname{Rate}(\mu \mathrm{mol} / \mathrm{min})=$

$1.36 \times 10^{4}$

\subsection{Circular Dichroism Studies}

Circular Dichroism spectroscopy (CD) is a powerful tool for revealing any conformational change to the protein structure. The far-UV CD region (190-260 nm ), which corresponds to peptide bond absorption, was analyzed by an AVIV Model 215 Spectropolarimeter (Lakewood, NJ, USA) to give the content of regular secondary structure of AChE. Protein solutions were prepared in the same buffer as used for the enzymatic assay. Protein solutions of $0.4 \mathrm{mg} / \mathrm{mL}$ were used to obtain the spectra after being incubated with different concentrations of sodium selenate $(0,390,870,1300$ and $1800 \mu \mathrm{M})$ in the presence and absence of ELF-EMF at $4{ }^{\circ} \mathrm{C}$. The CD spectrum of AChE, with different concentrations of sodium selenate was recorded under ELF- EMF at 200 to $250 \mathrm{~nm}$ using a quartz cell with the path length of $0.1 \mathrm{~cm}, 0.2 \mathrm{~nm}$ resolution, $20 \mathrm{~nm} / \mathrm{min}$ scan speed, $2.0 \mathrm{~s}$ time constant, $10 \mathrm{~nm}$ band width and the sensitivity of $20 \mathrm{~m}^{\circ}$.

\subsection{Intrinsic Fluorescence}

Intrinsic fluorescence intensity measurements were carried out using a Hitachi 
spectrofluorometer (MPF-4 model), equipped with a thermostatically controlled cuvette compartment. The intrinsic emission of $3 \mu \mathrm{M}$ protein was seen at the excitation wavelength of $280 \mathrm{~nm}$. The conditions of incubation were the same as those used for CD studies.

\subsection{Preparation of Sodium Selenate}

7.9 grams of so-called standard Se (99.9\%) were dissolved in $13 \mathrm{ml}$ of warm $65 \%$-nitric acid. The selenious acid, $\mathrm{H}_{2} \mathrm{SeO}_{3}$, obtained, 1.2 grams, was then admixed with a stoichiometric amount of $\mathrm{NaOH}, 8$ grams, as a $50 \%$-solution of sodium hydroxide, there being obtained 17.3 grams of Sodium selenite and a further 3.6 grams of water. The $\mathrm{pH}$ was adjusted to 11 , by adding a further minor amount of $\mathrm{NaOH}$. Hydrogen peroxide $(30 \%)$ was then stirred into the Sodium selenite solution in a stoichiometric excess, at a temperature of $70^{\circ} \mathrm{C}$., the Sodium selenite being oxidized to $\mathrm{Na}_{2} \mathrm{SeO}_{4}$. The resultant solution, contained Sodium selenite, and then we put down on a flat place and the supernatant solution was separated, then its concentration determined by Inductively Coupled Plasma (ICP, Varian VISTA-MPX).

The chemical reactions involved in the method are:

$\mathrm{Se}+\mathrm{HNO}_{3} \longrightarrow \mathrm{H}_{2} \mathrm{SeO}_{3}+\mathrm{NOXH}_{2} \mathrm{SeO}_{3}+2 \mathrm{NaOH} \longrightarrow \mathrm{Na}_{2} \mathrm{SeO}_{3}+2 \mathrm{H}_{2} \mathrm{O}$

Or alternatively: $\mathrm{H}_{2} \mathrm{SeO}_{3}+\mathrm{Na}_{2} \mathrm{CO}_{3} \longrightarrow \mathrm{Na}_{2} \mathrm{SeO}_{3}+\mathrm{CO}_{2} \mathrm{Na}$

$\mathrm{Na}_{2} \mathrm{SeO}_{3}+\mathrm{H}_{2} \mathrm{O}_{2} \longrightarrow \mathrm{Na}_{2} \mathrm{SeO}_{4}+\mathrm{H}_{2} \mathrm{O}$

\section{$2.5 E L F-E M F$}

ELF-EMF was generated by a parallel set of Helmholtz solenoids with 500 turns of $0.7 \mathrm{~mm}$ coated copper wire. Each solenoid diameter was $27 \mathrm{~cm}$. The coils were driven by 50, 100 and $217 \mathrm{HZ}$ power through a variable transformer and generated a magnetic flux density of 0.3 $\mathrm{mT}$. The samples were placed in the center half way between the plains of coils to receive a uniform field for $30 \mathrm{~min}$. Attention was paid to eliminate all the metal elements around the field.

\subsection{Statistical Analysis}

Statistical analysis was performed by SPSS software using one way variance analysis ANOVA (Ver. 16, IBM Corporation, USA). Data were reported as mean \pm standard deviation at significance level of $\mathrm{p}<0.05$.

\section{Results}

\subsection{UV-Visible Absorption Spectra}

The effect of sodium selenate on the activity of AChE can be determined by carrying out a series of velocity measurements in the presence of different concentrations of sodium selenate with and without ELF-EMF. As shown in Figure 1, AChE activity decreased by increasing the sodium selenate concentration. Figures $2 a-2 c$, demonstrate a decrease in the enzyme activity in presence of increased concentrations of sodium selenate under ELF-EMF. 


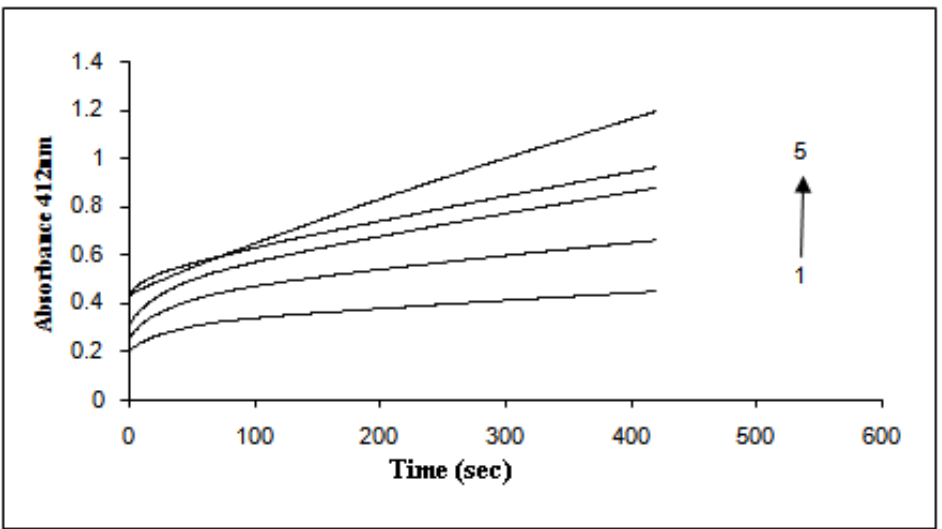

Figure 1. Absorption spectra of AChE in the presence of different concentrations of sodium selenate: 1: 1800, 2: 1300, 3: 870, 4: 390, 5: $0 \mu \mathrm{M}$ after incubation for $30 \mathrm{~min}$ at $4{ }^{\circ} \mathrm{C}$.

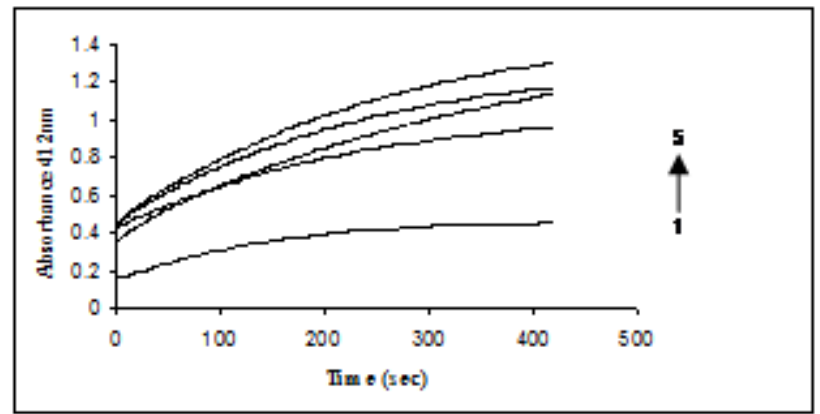

$a$

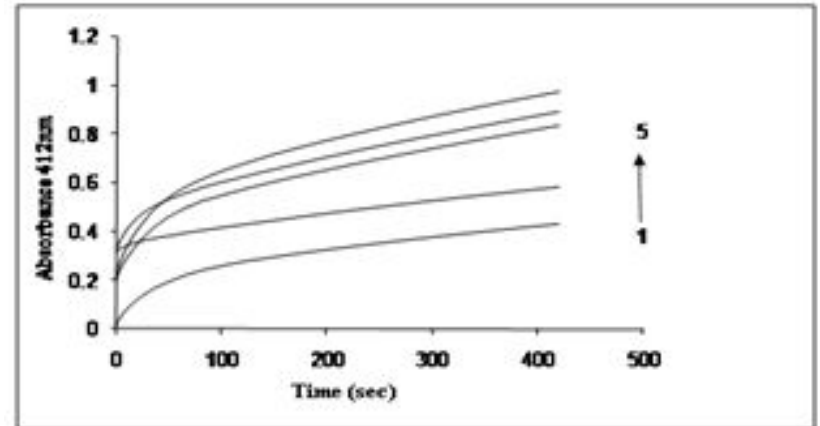

$b$

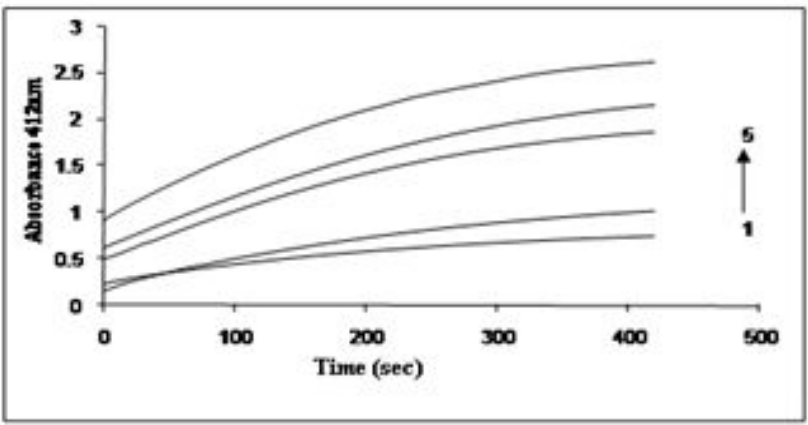

$c$

Figure 2. Absorption spectra of AchE at different concentrations of sodium selenate: 1: 1800, 


\section{Macrothink}

2: 1300, 3: 870, 4: 390, 5: $0 \mu \mathrm{M}$ after incubation for 30 min under the frequency of a:50 Hz , b: $100 \mathrm{~Hz}, \mathrm{c}: 217 \mathrm{~Hz}$ and the intensity of $0.3 \mathrm{mT}$ at $4{ }^{\circ} \mathrm{C}$.

\subsection{Circular Dichroism Studies}

Far-UV CD spectra (190-260 nm) are used for the determination of a proteins' secondary structure. The peptide bond is the principal absorbing group. Studies in this region may provide information about the secondary structure of a protein (Sreerama and Woody, 2004; Saboury et al., 2004). During the present analysis, in order to consider the effect of different concentrations of sodium selenate, at different frequencies of ELF-EMF, on the conformational changes of AChE, Far-UV CD technique was used and the spectra can be observed in Figure 3. The CD spectra of AChE exhibited two negative minima at $208 \mathrm{~nm}$ and $222 \mathrm{~nm}$, which is a typical characterization of the helical structure of this class of proteins (Hu et al., 2005). Figures 3b-d demonstrate the reduction of helicity of AChE in the presence of increasing concentrations of sodium selenate under 50, 100 and $217 \mathrm{~Hz}(0.3 \mathrm{mT})$. Within the wavelength region of $205-250 \mathrm{~nm}$, the CD spectrum of a protein gives information about its conformation in relation to the secondary structure. The ELF-EMF decreases both of these bands, clearly indicating the decrease of helical content in the protein in the presence of 50, 100 and $217 \mathrm{~Hz}(0.3 \mathrm{mT})$.

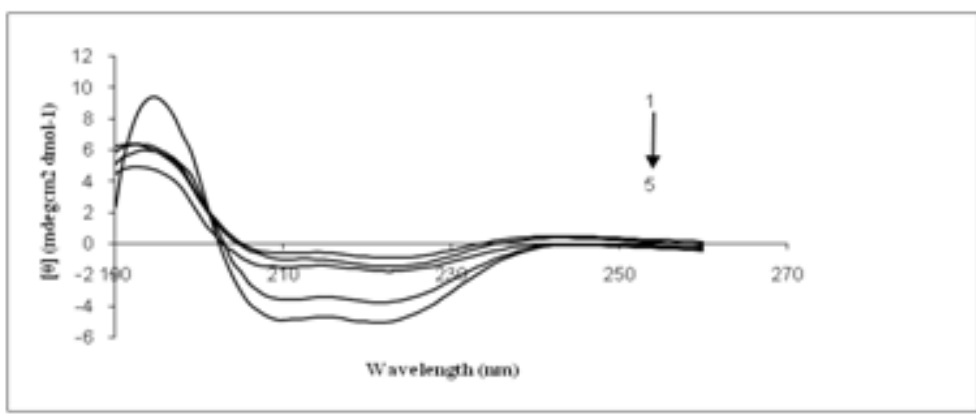

$a$

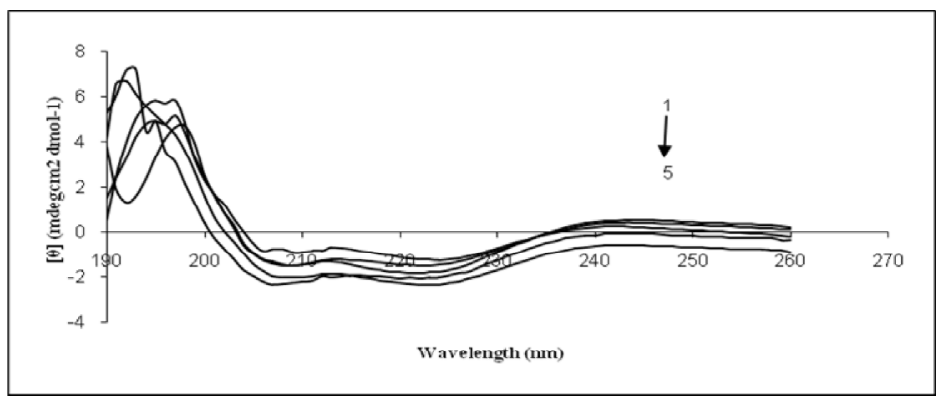

b 


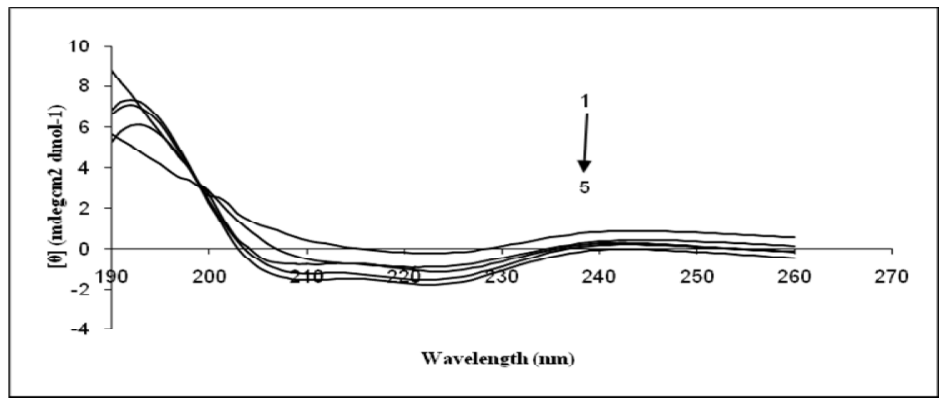

$c$

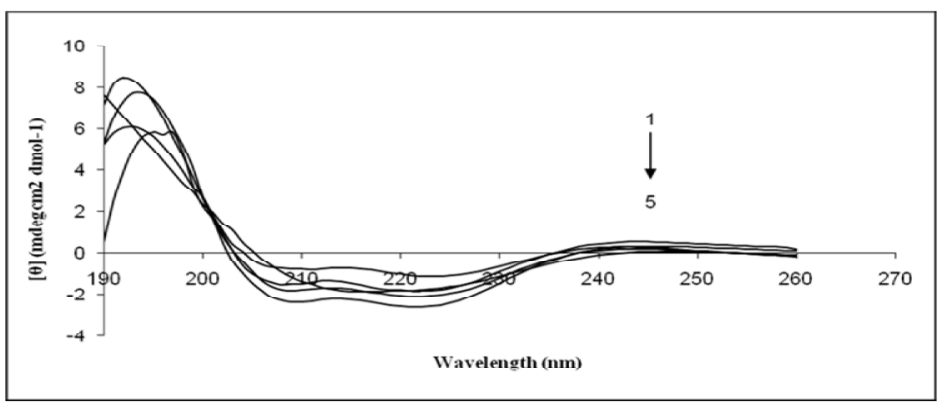

d

Figure 3. UV-CD spectra of AChE at different concentrations of sodium selenate: 1: 1800, 2: 1300, 3: 870, 4: 390, 5: $0 \mu \mathrm{M}$ after incubation for $30 \mathrm{~min}$ at $4{ }^{\circ} \mathrm{C} \quad$ a: without ELF-EMF b: in the presence of $50 \mathrm{~Hz}, \mathrm{c}: 100 \mathrm{~Hz}$ and $\mathrm{d}: 217 \mathrm{~Hz}$.

\subsection{Fluorescence Studies}

Intrinsic Trp fluorescence was used to monitor changes in the protein conformation in the presence of different concentrations of sodium selenate after incubation for $30 \mathrm{~min}$. at $25^{\circ} \mathrm{C}$ in the presence of 50, 100 and $217 \mathrm{~Hz} \mathrm{0.3mT} \mathrm{(Figure} \mathrm{4).}$

Figure $4 \mathrm{a}$ shows the intrinsic fluorescence emission spectra of $\mathrm{AChE}$ in the presence of sodium selenate and without ELF-EMF. Figures $4 b-d$ illustrate the intrinsic fluorescence emission spectra of $\mathrm{AChE}$ in the presence of different concentrations of sodium selenate under 50, 100 and $217 \mathrm{~Hz}(0.3 \mathrm{mT})$, respectively. Figures $4 \mathrm{~b}, 4 \mathrm{c}$ and $4 \mathrm{~d}$ demonstrate a decrease in the intrinsic fluorescence by increasing the sodium selenate concentrations. Figure $4 \mathrm{a}$ shows the plots of maximum emission intensity at $341 \mathrm{~nm}$ but figures $4 \mathrm{~b}-4 \mathrm{~d}$ show the plots of maximum emission intensity at $50 \mathrm{~nm}$. Therefore, we have observed the wavelength shift during the present experiment. According to these figures, it is interesting to point out that in the presence of 50,100 and $217 \mathrm{~Hz}(0.3 \mathrm{mT})$, the protein had more accessible hydrophobic patch than that without ELF-EMF, for sodium selenate. 


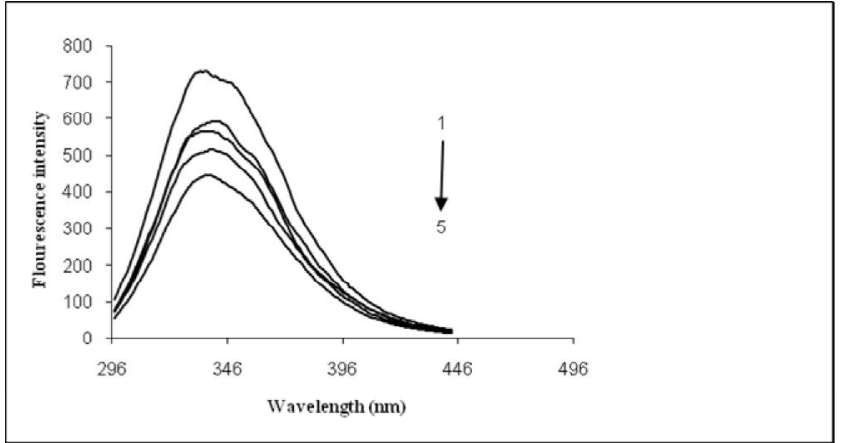

a

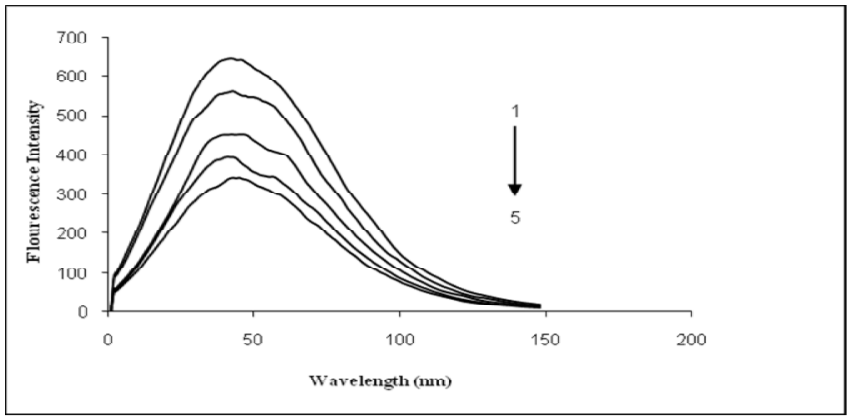

b

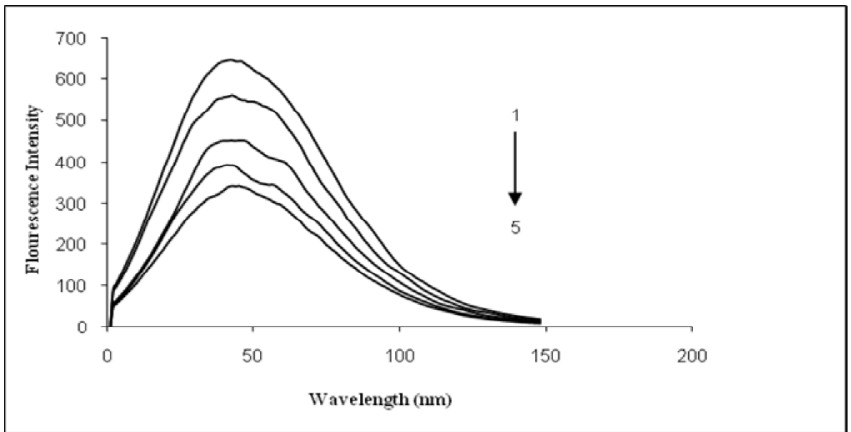

c

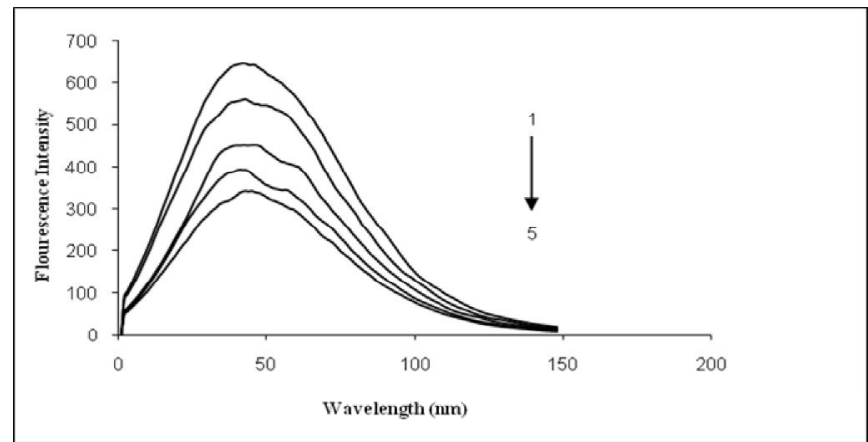

d

Figure 4. Chart of intrinsic emission of $\mathrm{AChE}$ at different concentrations of sodium selenate: 1:0, 2:390, 3:870, 4:1300, 5:1800 $\mu \mathrm{M}$ after incubation for $30 \mathrm{~min}$ at $4{ }^{\circ} \mathrm{C}$, and different frequencies with $0.3 \mathrm{mT}$ field intensity. 4a: without ELF-EMF, 4b: $50 \mathrm{~Hz}, 4 \mathrm{c}: 100 \mathrm{~Hz}$ and 4d: $217 \mathrm{~Hz}$. 


\section{Discussion}

Exposures to many EMF frequencies are increasing significantly as technology advances unabated and new applications are found. During the past 20 years the general public has become increasingly concerned about potential adverse health effects of exposure to electric and magnetic fields at ELF. The effects of electromagnetic fields on living microorganisms have been investigated for a long time. In one previous study, EMF affects some biochemical processes and result in changing some serum biochemical parameters and enzymes (yaghmaei et al., 2009). This research as well as previous researchers strongly suggested that the field action is mediated by the structure which is crucial in determining the conditions of the enzyme inactivation (Ravera et al., 2004). Investigation on the role of selenium in biological systems is very important. Many studies have been done over the years to demonstrate the effects of selenium: helps promote a healthy liver, acts as an antioxidant against free radicals (Abubakar et al., 2004), may help prevent cancers (Fleet et al., 1997), protects against toxic metals in the body including mercury (Ani et al., 2007; moshtaghie et al., 2007) and protects against heart disease (Cardoso et al., 2010). In the present study, UVvis spectroscopy, $\mathrm{CD}$ and fluorescence techniques have been used to monitor the changes of structure of AChE under the frequency of 50,100 and $217 \mathrm{~Hz}$ and the intensity of $0.3 \mathrm{mT}$ in the presence of different concentrations of $\mathrm{Na}_{2} \mathrm{SeO}_{4}$. Activity studies (Figure.1) showed that different concentrations of $\mathrm{Na}_{2} \mathrm{SeO}_{4}$ have an effect on the activity of AChE under ELF-EMF. ELF-EMF substantially alters the optimal temperature and optimal $\mathrm{pH}$. However, there was a change in OD values when the samples were exposed to ELF-EMF at different frequencies which indicate there was alternation in enzyme activity. Previous studies revealed that application of ELF-EMF on enzymes such as Lipid peroxidase, Adenylate Kinase and Phosphatase under the field of $120 \mathrm{mT}$ and $180-195 \mathrm{~Hz}, 250 \mathrm{mT}$ and $75 \mathrm{~Hz}, 5 \mathrm{mT}$ and $50 \mathrm{~Hz}$ caused to reduction on enzyme activity, respectively (Ravera et al., 2004). CD has proved to be an ideal technique to monitor conformational changes in proteins, which can occur as a result of changes in experimental parameters such as $\mathrm{pH}$, temperature, binding of ligands and so on (Kelly and Price, 2000). Far-UV CD studies of AChE under ELF-EMF at different concentrations of $\mathrm{Na}_{2} \mathrm{SeO}_{4}$ showed significant affected of $\mathrm{Na}_{2} \mathrm{SeO}_{4}$ under ELF-EMF on the secondary structure of the protein. The protein has alpha/beta structure (Axelsen et al., 1994; Fathi and Farahzadi, 2012) while in the presence of $390,870 \mu \mathrm{M}$ concentrations of $\mathrm{Na}_{2} \mathrm{SeO}_{4}$ the content of $\alpha$-helix structure of AChE was decreased and at a concentration of $1300 \mu \mathrm{M}$ of $\mathrm{Na}_{2} \mathrm{SeO}_{4}$ a transition from $\alpha$-helix to $\beta$-structure was appeared (Figure 3 ) then, it can be concluded that with increasing the concentrations of $\mathrm{Na}_{2} \mathrm{SeO}_{4}, \beta$-sheet structure can induce in the secondary structure of AChE under ELF-EMF and consequently prevent the access of the substrate (ACh iodide) to the enzyme active site. $\mathrm{Na}_{2} \mathrm{SeO}_{4}$ induced changes in intrinsic fluorescence intensity of the Trp residues in AChE under ELF-EMF: with increasing the concentrations of $\mathrm{Na}_{2} \mathrm{SeO}_{4}$, Trp fluorescence decreased. Combining the results from UV-vis, Far-UV CD and intrinsic fluorescence analysis, we conclude that the structure of AChE under ELF-EMF is altered by $\mathrm{Na}_{2} \mathrm{SeO}_{4}$. Neuropathological studies have been reported that various antioxidants are decreased in different age-related degenerative diseases and thus, oxidative stress would have a central role in the pathogenesis of many disorders that involve neuronal 
degeneration, including Alzheimer's disease (AD). AD was associated with deficiency in the brain neurotransmitter, ACh (Tabet, 2006). The inhibition of AChE enzyme, which catalyzes the breakdown of ACh, may be one of the most realistic approaches to the symptomatic treatment of $\mathrm{AD}$ (Pangestuti and Kim, 2010). Therefore, we suggest that the $\mathrm{Na}_{2} \mathrm{SeO}_{4}$ in the presence of ELF-EMF could be useful in treatment of AD disease.

\section{Conclusion}

In conclusion, our results suggested that ELF-EMF application affects the AChE activity, while increasing sodium selenate concentration had same effect. These effects might be related to structural changes of the AChE.

\section{Acknowledgments}

The present study was supported by a research grant from the University of Tabriz.

\section{References}

Abubakar, M. G., Taylor, A., \& Ferns G. A. (2004). The effects of aluminium and selenium supplementation on brain and liver antioxidant status in the rat. African Journal of Biotechnology, 3, 88-93.

Ani, M., moshtaghie, A. A., \& Aghadavood M. (2007). Protective effects of selenium and zinc On the brain acetylcholinesterase activity in lead intoxified rat. Pharmaceutical Sciences, $2,80-84$.

Axelsen, P. H., Harel, M., Silman, I., \& Sussman J. L. (1994). Structure and dynamics of the active site gorge of acetylcholinesterase. Synergistic use of molecular dynamics simulation and X-ray crystallography. Protein Science, $3, \quad$ 188-197. http://dx.doi.org/10.1002/pro.5560030204

Cardoso, B. R., Ong, T. P., Jacob-Filho, W., Jaluul, O., Freitas, M., \& Cozzolino S. (2010). Nutritional status of selenium in Alzheimer's disease patients. British Journal of Nutrition, 103, 803-6. http://dx.doi.org/10.1017/S0007114509992832

Axelsen, P. H., Harel, M., Silman, I., \& Sussman J. L. (1994). Structure and dynamics of the active site gorge of acetylcholinesterase. Synergistic use of molecular dynamics simulation and X-ray crystallography. Protein $\quad$ Science, $\quad 3, \quad 188-197$. http://dx.doi.org/10.1002/pro.5560030204

Dvir, H., Harel, M., Bon, S., \& Silman I. (2004). The synaptic acetylcholinesterase tetramer assembles around a polyproline II helix. EMBO Journal, 23, 4394-4405. http://dx.doi.org/10.1038/sj.emboj.7600425

Ellman, G. L., Curtney, K. D., Andres, V., \& Featherstone R. M. (1961). A new and rapid colorimetric determination of acetylcholinesterase activity. Biochemical Pharmacology, 7, 88-95. http://dx.doi.org/10.1016/0006-2952(61)90145-9

Fathi, E., \& Farahzadi R. (2012). Effect of Electromagnetic Field on Acetylcholinesterase activity: in vitro Stud. African Journal of Biochemistry Research, 6, 8-13. 
Fleet J. C. (1997). Dietary selenium repletion may reduce cancer incidence in people at high risk who live in areas with low soil selenium. Nutrition Review, 55, 277-9. http://dx.doi.org/10.1111/j.1753-4887.1997.tb01617.x

Hekmat, A., Saboury, A. A., Divsalar, A., \& Khanmohammadi M. (2008).Conformational and structural changes of choline oxidase from Alcaligenes species by changing $\mathrm{pH}$ Values. Bulletin of the Korean Chemical Society, 29, 1510-1518. http://dx.doi.org/10.5012/bkcs.2008.29.8.1510

Kelly, S. M., \& Price N. C. (2000). The use of circular dichroism in the investigation of protein structure and function. Current Protein \& Peptide Science, 1, 349-384. http://dx.doi.org/10.2174/1389203003381315

Morelli, A., Ravera, S., Panfoli, I., \& Pepe I.M. (2005). Effects of extremely low frequency electromagnetic fields on membrane-associated enzymes. Archives of Biochemistry and Biophysics, 441, 191-198. http://dx.doi.org/10.1016/j.abb.2005.07.011

moshtaghie, A. A., Ani, M., Aghadavood, E., \& Fazilati M. (2007). Protective effects of selenium and zinc on Changes in Catecholamine Levels of Brain Regions in Lead Intoxified Rat. Pakistan Journal of Biological Sciences, 10, 2964-2967.

Pangestuti, R., \& Kim S. K. (2010). Neuroprotective properties of chitosan and its derivatives. Marine Drugs Journal, 8, 2117-2128. http://dx.doi.org/10.3390/md8072117

Ravera, S., Repaci, E., Morelli, A., Pepe, I. M., Botter, R., \& Beruto D. (2004). Electromagnetic field of extremely low frequency decreased adenylate kinase activity in retinal rod outer segment membranes. Bioelectrochemistry, 63, 317-20. http://dx.doi.org/10.1016/j.bioelechem.2003.10.029

Saboury, A. A., Karbassi, F., Ranjbar, B., Haghbeen, K., Moosavi-Movahedi, A. A., \& Farzami B. (2004). Stability, structural and suicide inactivation changes of Mushroom tyrosinase after acetylation by $\mathrm{N}$-acetylimidazol. International Jounal of Biological Macromolecules, 34, 257-262. http://dx.doi.org/10.1016/j.ijbiomac.2004.06.003

Sreerama, N., \& Woody R.W. (2004). On the analysis of membrane protein circular dichroism spectra. Protein Science, 13, 100-112. http://dx.doi.org/10.1110/ps.03258404

Tabet N. (2006). Acetylcholinesterase inhibitors for Alzheimer's disease: Anti-inflammatories in acetylcholine clothing!, Age and Ageing (AGE), 35, 336-338. http://dx.doi.org/10.1093/ageing/af1027

Yaghmaei, P., Parivar, k., Doranian, D., Hashemi, M., \& Torkaman F. (2009). Study on the effect of extremely low frequency electromagnetic fields on some blood serum's lipoproteins, liver enzymes and P 448/P 450 cytochrome enzyme system in NMRI mice. Journal of Paramedical Sciences (JPS), 1, 1735-7802.

Zwirska-Korczala K. (2005). Effect of extremely low frequency electromagnetic fields on cell proliferation, antioxidative enzyme activities and lipid peroxidation in 3T3-L1 predipocytes- an in vitro study. Journal of Physiology and Pharmacology, 56, 101-108. 


\section{Copyright Disclaimer}

Copyright reserved by the author(s).

This article is an open-access article distributed under the terms and conditions of the Creative Commons Attribution license (http://creativecommons.org/licenses/by/3.0/). 